\title{
RAILWAYS CONTRIBUTION TO NATIONAL SECURITY
}

\author{
Lecturer Petrişor Gabriel PEIU, Ph.D. ${ }^{77}$ \\ Lecturer Florin Codruţ NEMŢANU, Ph.D. ${ }^{78}$
}

\begin{abstract}
The railways system has a tremendous influence to the national security. First of all, railways development is strongly pushing the GDP growth for any country, as being a very elaborate industry and having a very large in the railways supply industry (RSI). Second of all, the industries which are contributes to the RSI are the high end of the specific domains and all of the new systems in the network is often coming with very sophisticated and new products, having an important contribution to the research and development $(R \& D)$ departments. And, thirdly, railways and highways are creating a more cohesive EU and is creating a high level of connectivity for all the member states. Connectivity is the key feature for a better mobility for the humans' resources and for material resources. If the EU gains in connectivity any potential enemy of any member state will understand that the given member state could easily and timely benefit from the resources of all the member states. A better connectivity will also bring the US and UK military capabilities closer to any member state.
\end{abstract}

Keywords: Railway, national security, mobility, connectivity, GDP growth, railway supply industry.

\section{NATIONAL SECURITY DEFINITION AND MAIN CONSTITUENTS}

Despite the various way to define "national security", the concept is easy to understand. A broader definition might be considered the following: "National security then is the ability to preserve the nation's physical integrity and territory; to maintain its economic relations with the rest of the world on reasonable terms; to preserve its nature, institution, and governance from disruption from outside; and to control its borders." (Harold Brown, U.S. Secretary of Defence, 1977-1981) ${ }^{79}$.

Obvious, the elements to contribute to the wider "national security" are the following:

- economic security;

- energy security;

- physical security;

\footnotetext{
${ }^{77}$ Dr. Petrişor Gabriel Peiu is Lecturer at the University `Politehnica“ from Bucharest, Department of Transport and coordinator of the Department of Economic Analysis of the Black Sea University Foundation (FUMN). Dr. Peiu previously served as Advisor of the Prime Minister Radu Vasile (1998-1999) and Adrian Năstase (20012002).

${ }^{78}$ Dr. Florin Codruţ Nemţanu, Ph.D. is Lecturer at the University `Politehnica` from Bucharest, Department of Transport.

${ }^{79}$ Harold Brown (1983), Thinking about national security: defense and foreign policy in a dangerous world, as quoted in Watson, Cynthia Ann (2008), U.S. national security: a reference handbook. Contemporary world issues (2 (revised) ed.). ABC-CLIO. pp. 281. ISBN 978-1-59884-041-4, https://archive.org/details/ usnationalsecuri0000wats, accessed at 01.05.2021.
} 
- environmental security;

- food security;

- border security;

- cyber security.

All these dimensions of the security of a nation are closely correlate with the main components of the given nation`s power.

Railways are involved in the majority of these elements, such as economic security is enhanced by a good transportation network, which could improve the trade with other nations, particularly with its own allies. Also, the energy security is supported by a good freight network, in order to benefit from the primary energy resources abundance.

Railways brings more environmental security by being "largely electrified and emits far less $\mathrm{CO} 2$ than equivalent travel by road or air. It accounts for only $0.4 \%$ of greenhouse gas emissions from EU transport, while all EU transport accounts for $25 \%$ of the EU's total emissions. Plus, it is the only transport means that between 1990-2017 has consistently reduced its emissions and energy consumption, while increasingly using renewable energy sources" $"$.

While rail transport is generating only $0,4 \%$ of the greenhouse gas emissions of the EU transport sector (EU 27-2018), the road transport is generating almost three fourths $(71.8 \%)$ of the greenhouse gas emissions and one seventh $(14.1 \%)$ of these emissions is produced by the waterborne transport and another one seventh $(13.2 \%)$ by the civil aviation.

Food security is also increasingly dependent by rail transport, taking into consideration the huge quantities of agriculture commodities to be delivered by train.

However, national security in EU is not only "national". It is more EU-level security and NATO-level security. Member states are decisively relying on the EU level approach on issues related to security, including the military approach. Therefore, transport is one of the core pillars of the EU solidarity and is the base of European integration. Even if the aim of a EU common transport policy is to safeguard both competition and the freedom to provide services, the creation of a Single European Railway Area is creating a new and powerful instrument of the common security, strengthening the capability to transfer important amounts of resources (including military ones) to the member state in danger from enemies.

The fast and effective international rail transport of passengers brings additional solidarity between citizens of the member states and contributes to a global "European" feeling.

Particularly for the eastern countries (former socialist countries- which are basically free of US troops) the development of the rail corridors in Europe

80 European Year of Rail, European Commission, Directorate-General for Mobility and Transport, https://europa.eu/year-of-rail/why-rail_en, accessed at 01.05.2021. 
generates reasonable expectations of support (in the case of any unfortunate event) from the American and British armies located in the west of the continent.

\section{ECONOMIC AND SOCIAL FOOTPRINT OF THE RAILWAY INDUSTRY IN EU}

In the year 2012, rail industry accounts for 1.06 million of persons direct and 1.21 million of persons indirect employed (EMPL). Rail industry creates in that year 66 billion Euro direct gross value added and 77 billion gross values added, which is, in total, over $4.2 \%$ of the gross value added at EU level ${ }^{81}$.

Rail transport creates more direct value added than air or water transport in the same year, 2012:

- 32 billion Euro for the water transport,

- 53 billion Euro for the air transport

- 66 billion Euro for the rail transport ${ }^{82}$.

In that year, rail`s labour productivity has overtaken the economy-wide range into the EU market: over 60, 000 Euro/employed person in the rail industry vs. 50,000 Euro/employed person in the economy-wide range.

EU's railway supply industry (RSI) is the largest in the world and accounts for 27 billion Euro turn-over in 2012, which is about $20 \%$ of the global turnover of the RSI industry. The R\&D intensity (4 - 10\% of industry) is very high, more than double than for the economy-wide range.

\section{RAIL TRANSPORT CONTRIBUTION TO ECONOMIC DEVELOPMENT}

The map of EU countries by economic performance in the year 2019 is shown in the picture bellow (see map in Fig.1), as having the GDP/capita, PPS (purchasing parity standard) the global indicator for economic performance ${ }^{83}$ :

\footnotetext{
${ }^{81}$ The Economic Footprint of Railway Transport in Europe, Ecorys for Client: Community of European Railway and Infrastructure Companies (CER), Brussels, October 2014, https://www.cer.be/sites/ default/files/publication/The_Economic_Footprint_-_web_-_final_final_30_Sept_0.pdf, accessed at 01.05.2021.

${ }^{82}$ The Economic Footprint of Railway Transport in Europe, op.cit.

${ }^{83}$ Regional GDP per capita ranged from $32 \%$ to $260 \%$ of the EU average in 2019, European Commission, Eurostat, 03/03/2021, https://ec.europa.eu/eurostat/web/products-eurostat-news/-/ddn-20210303-1, accessed at 01.05.2021.;
} 


\section{GDP per capita in EU regions (NUTS 2), 2019} (in PPS, $E U=100$ )

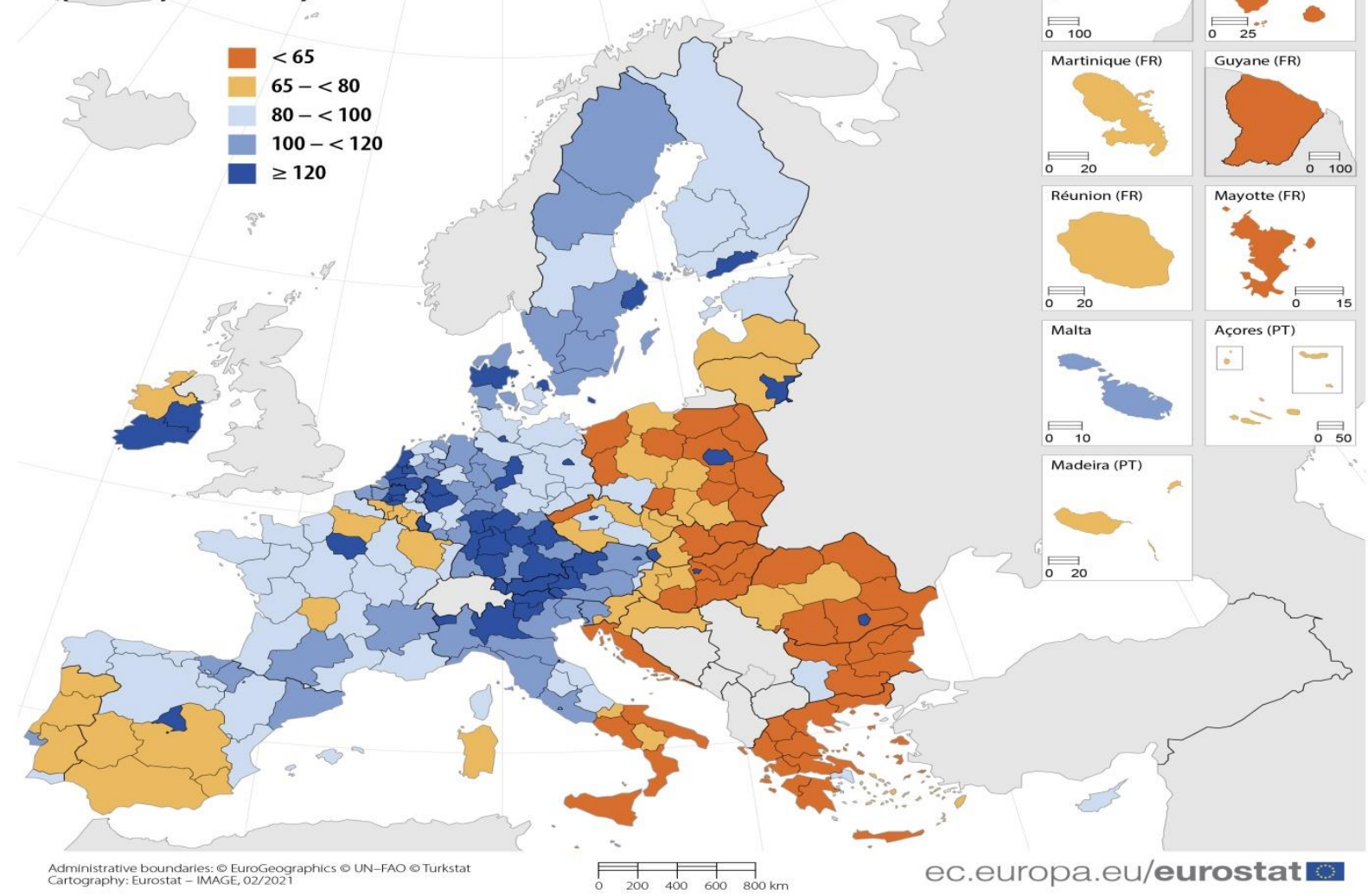

Fig. 1: GDP per capita in EU regions (NUTS 2), 201 - EUROSTAT9 ${ }^{84}$

The best performers are the regions in the centre and in the north of the EU, in Germany, Netherlands, Belgium, Austria, Sweden, north of Italy, north of Spain and France. All these regions are enjoying a level of GDP/capita, PPS over $80 \%$ of the EU average. In the German Western lands, in the Netherlands, in Belgium, in Austria and in the Northern Italy and Southern France the level of GDP/capita, PPS is over the EU average and is increasing just in the core of this territory, across the line from the northern ports of Hamburg, Rotterdam and Antwerp to the Lombardy, Piedmont, Veneto and Tuscany.

The most intense the economy works, the most intense is the railway density (see map in Fig.2). The regions with highest economic performance are also the regions with highest railway density in the EU: Germany, Western France, Belgium, Netherlands, northern Italy and Austria. Plus, the most dynamic and developed economies in the Central and East Europe (CEE), Czech Republic and Poland ${ }^{85}$ :

\footnotetext{
${ }^{84}$ https://ec.europa.eu/eurostat/documents/4187653/11571499/GDP_per_capita_ver3-01.jpg, accessed at 01.05 2021.

85 Inland transport infrastructure at regional level, Eurostat, Statistics Explained, https://ec.europa.eu/eurostat/statistics-explained/index.php?title=Inland_transport_infrastructure_at_regional_ level\&oldid=482435\#Railways, accessed at 01.05.2021.
} 


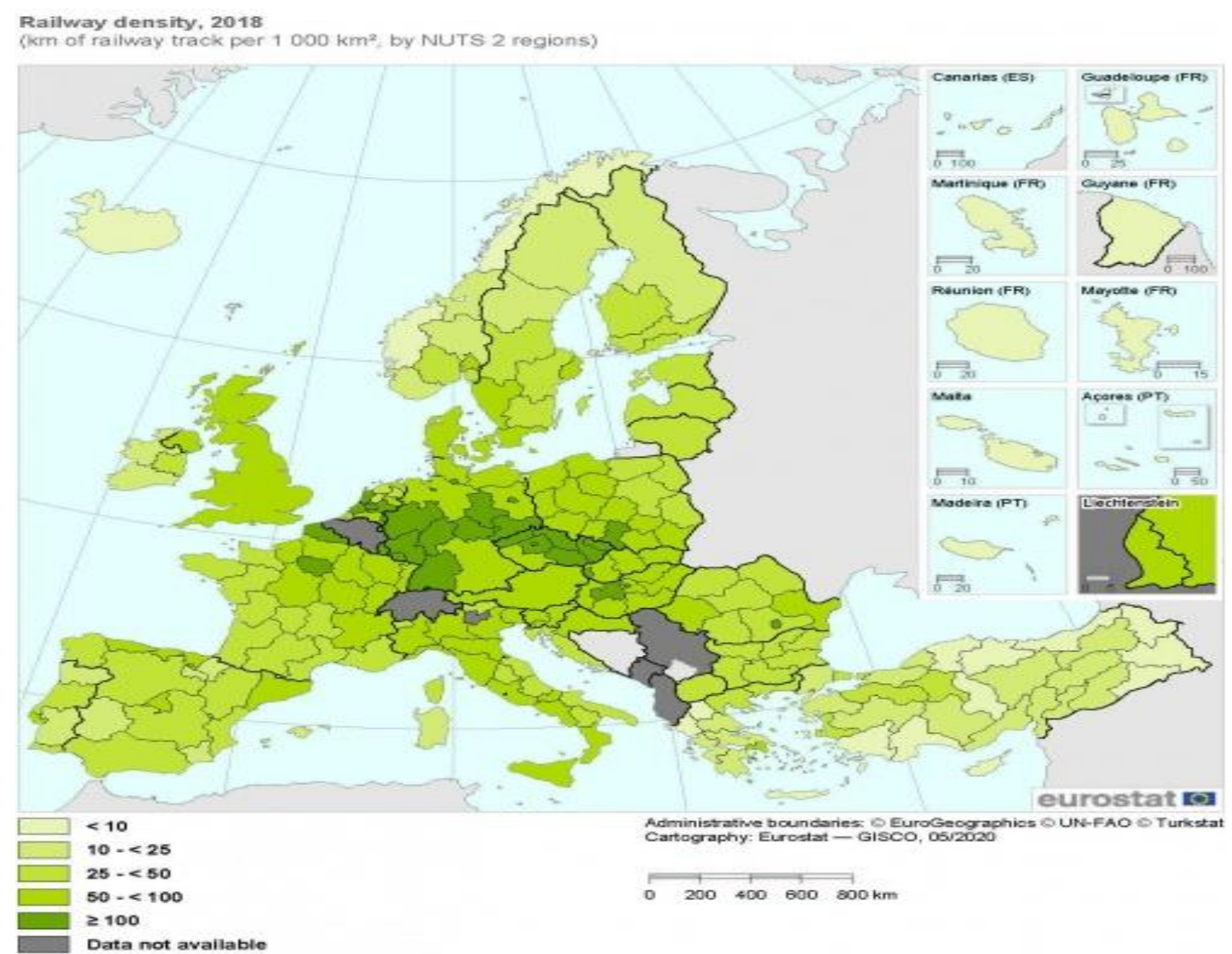

Data not avallable

Fig. 2: Railway density 2018 - EUROSTAT ${ }^{86}$

\section{RAIL TRANSPORT CONTRIBUTION TO ENVIRONMENTAL SECURITY}

Rail transport generates, in the year 2015 , about $40 \mathrm{gCO}_{2} /$ passenger-km, much lower than the figures for the passenger car transport and air transport (both of them about $110 \mathrm{gCO} 2 /$ passenger- $\mathrm{km}$. This shows the fact that rail transport is about three times less pollutant.

For the freight, the figures are more advantageous: the rail freight generates about $20 \mathrm{gCO} 2 /$ tonne- $\mathrm{km}$, three times lower than the barge freight $(60 \mathrm{gCO} 2 /$ tonne- $\mathrm{km})$ and about four times lower than the truck freight (about $80 \mathrm{gCO} 2 /$ tonne-km) ${ }^{87}$.

\footnotetext{
${ }^{86} \mathrm{https}: / /$ ec.europa.eu/eurostat/statistics-

explained/images/e/eb/Railway_density\%2C_2018_\%28km_of_railway_lines_per_1_000_km\%C2\%B2\%2C_by _NUTS_2_regions\%29_RYB20.jpg, accessed at 01.052021.

87 Greenhouse gas emissions: a decisive asset for rail?, https://www.climate-chance.org/wp-content/ uploads/2019/03/new-greenhouse-gas-emissions-a-decisive-asset-for-rail.pdf, accessed at 01.05.2021.
} 
The above mentioned figures indicates the performance of rail transport in terms of load/emissions ratios. This results encouraged many governments to bet on rail to try to meet the general objectives of reducing carbon emissions. The European Union includes in the Resilience and Recovery Mechanism a pillar related to green transition, which brings serious financial resources to the member states, in order to switch as much as possible, the traffic from road and airplane to rail. Therefore, rail is the ultimate bet of the governments for reducing carbon dioxide emissions. As an example, Romania introduced in its Recovery and Resilience National Plan, as investments in railway network, an amount of 4.5 billion Euro out of the total 29.2 billion Euro of national allocation. This made rail transport the biggest beneficiary of the Romanian Recovery and Resilience National Plan.

The entire EU is focused on the "big switch of the modes of transport", the objective being very ambitious:

- to increase the rail share in passenger transport (passenger-km) with 50\% by 2030 compared with 2010 , and with $100 \%$ by 2050 ;

- to increase the rail share in land freight (tonnes-km), in order to equalise the road freight by 2030 and to have $50 \%$ higher the rail share than the road share in freight by 2050 .

\section{RAIL TRANSPORT CONTRIBUTION TO FOOD SECURITY}

EU is one of the biggest producers in the world for cereals, the oilseed complex and protein crops (COP). Therefore, it is highly important to have the capability to move such a big quantity of this commodities. Inland waterways and railways handle almost all long-distance COP tonnage (60-70\% for inland waterways, $30-40 \%$ for railways) along the four main COP transportation corridors (Baltic-Adriatic, North Sea-Baltic, Rhine-Alpine and Rhine-Danube); truck transportation prevails in short-distance moves. A better performance, allows rail transportation to be more efficient than road transportation in longhaul moves. All over the continent, there are large quantities of COP crops shipped by block trains or unit trains without being split up on route. These trains consist of few ten wagons "TADS" type, "covered hopper", with a volume of $80 \mathrm{~m}^{3}$ $\operatorname{each}^{88}$.

The most important EU producers and exporters of COP are France, Germany, Poland, Romania, Italy and Spain. Therefore, the largest share of rail transport for the COP are in Poland, followed by Germany and Romania. France, Germany and Poland enjoyed better quality of the rail infrastructure and allows longer trains (up to 750 meters) than Romania and Italy, which allows trains with

\footnotetext{
${ }^{88}$ Study on storage capacities and logistical infrastructure for EU agricultural commodities trade, Final Report, European Commission, Written by Areté s.r.l., November - 2017, https://ec.europa.eu/info/sites/default/files/foodfarming-fisheries/plants_and_plant_products/documents/storage-capabilities-cop-report_nov2017_en.pdf, accessed at 01.05.2021.
} 
maximum length of 650-700 meters. However, in order to export the COP`s, truck transport is used to cover the distance from farm to silo (few to tens of kilometers) and rail transport is used to cover the distance from silo to ports (tens to hundreds of kilometers).

The "top 25" international rail traffic flows of agricultural goods are illustrated in the map bellow as in the Fig.3:

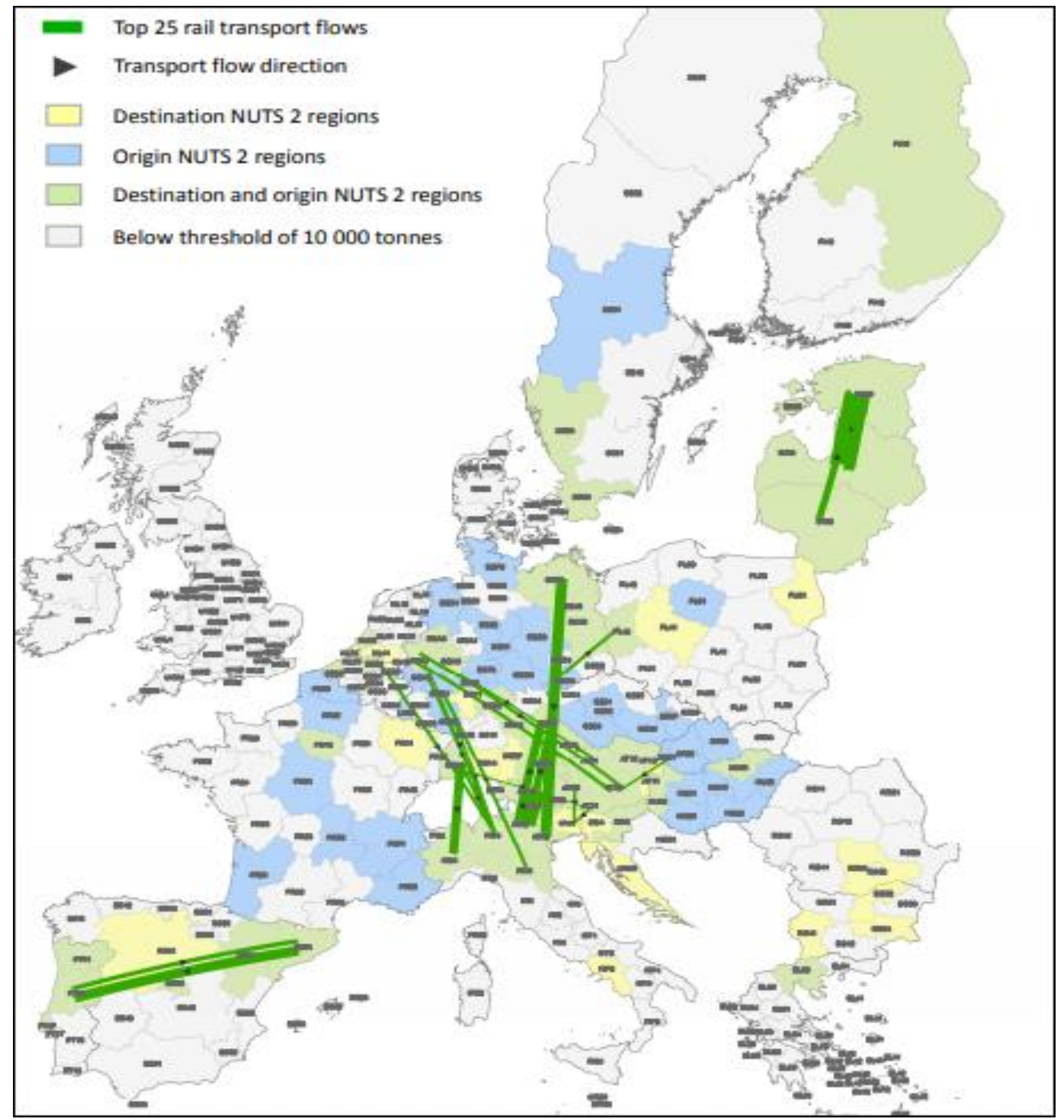

Fig. 3: Top 25 international rail transportation flows of agricultural goods in 2015,

Source: Study on storage capacities and logistical infrastructure for EU agricultural commodities trade, Final Report, European Commission, Written by Areté s.r.l., November - $2017^{89}$

\footnotetext{
${ }^{89}$ Study on storage capacities and logistical infrastructure for EU agricultural commodities trade, op.cit.
} 
In the table below are listed the most intense rail transport flows for agricultural goods ${ }^{90}$ :

\begin{tabular}{|c|c|c|c|c|c|}
\hline No. & Orlgin & NUTS 2 region & Destination & NUTS 2 region & Quantity in tonnes \\
\hline 1 & LVOO & atvila & EEOO & Eesti & 1221798 \\
\hline 2 & AT33 & Tirol & TH2 & Trento & 677982 \\
\hline 3 & DEBO & Mecklenburg-Vorpommem & TH3 & Veneto & 524328 \\
\hline 4 & ES51 & Cataluña & PT16 & Centro (P) & 505330 \\
\hline 5 & DE13 & Freiburg & $\mathrm{TC1}$ & Piemonte & 424190 \\
\hline 6 & ITH2 & Trento & pe23 & Oberpfalz & 420288 \\
\hline 7 & DE23 & Dberpfalz & TH2 & Trento & 390142 \\
\hline 8 & LTOO & Lithuanla & EEOO & Eesti & 342459 \\
\hline 9 & PT16 & Centro (P) & Es51 & Cataluhla & 226591 \\
\hline 10 & DE13 & Freiburg & TTC4 & Lombarda & 196872 \\
\hline 11 & ATZ2 & Steiermark & DEA1 & Dasseidorf & 185354 \\
\hline 12 & ITH2 & Trento & АT33 & Firol & 180469 \\
\hline 13 & DEA1 & posseldorf & Аा22 & Steiermark & 176424 \\
\hline 14 & DEB1 & Koblen2 & TH5 & Emilla: Romagna & 172946 \\
\hline 15 & DED4 & Chemnitz & PL43 & Lubuske & 164252 \\
\hline 16 & BE21 & Prov. Antwerpen & TC4 & Lombardla & 162610 \\
\hline 17 & AT32 & Salzburg & $\mathrm{TH} 4$ & Friuli-Venezia Gulla & 158173 \\
\hline 18 & DEA2 & koin & TC4 & Lombarda & 150808 \\
\hline 19 & DE22 & Niederbayern & AT31 & Dberbisterreich & 149784 \\
\hline 20 & AT21 & Kamten & $\mathrm{TH} 4$ & Friuli-Venezia Gulla & 131251 \\
\hline 21 & DEB3 & Fheinhessen.Pfalz & TC4 & Lombarda & 124527 \\
\hline 22 & SKD1 & Bratislwa region & Ат 22 & Steiermark & 124475 \\
\hline 23 & DEA1 & posseldorf & AT31 & Dberbisterreich & 115966 \\
\hline 24 & AT21 & Kamten & pE13 & Freiburg & 90857 \\
\hline 25 & DEA1 & posseldorf & TTC4 & Lombardia & 90744 \\
\hline
\end{tabular}

Table 1. Top 25 international rail transport flows of agricultural goods in 2015 , Study on storage capacities and logistical infrastructure for EU agricultural commodities trade, Final Report, European Commission, Written by Areté s.r.1., November - 2017, pg. $83^{91}$

Moving to the nation level, the "Top 100" national rail transportation flows of agricultural goods in 2015 shows a strong concentration of rail freight of COP in France, Sweden, Finland, Austria, Eastern Germany, Romania and Spain ${ }^{92}$.

\footnotetext{
${ }^{90}$ Ibidem.

${ }^{91} \mathrm{https} / / /$ ec.europa.eu/info/sites/default/files/food-farming-fisheries/plants_and_plant_products/documents/ storage-capabilities-cop-report_nov2017_en.pdf, accessed at 01.05.2021.

${ }^{92}$ Study on storage capacities and logistical infrastructure for EU agricultural commodities trade, op.cit.
} 


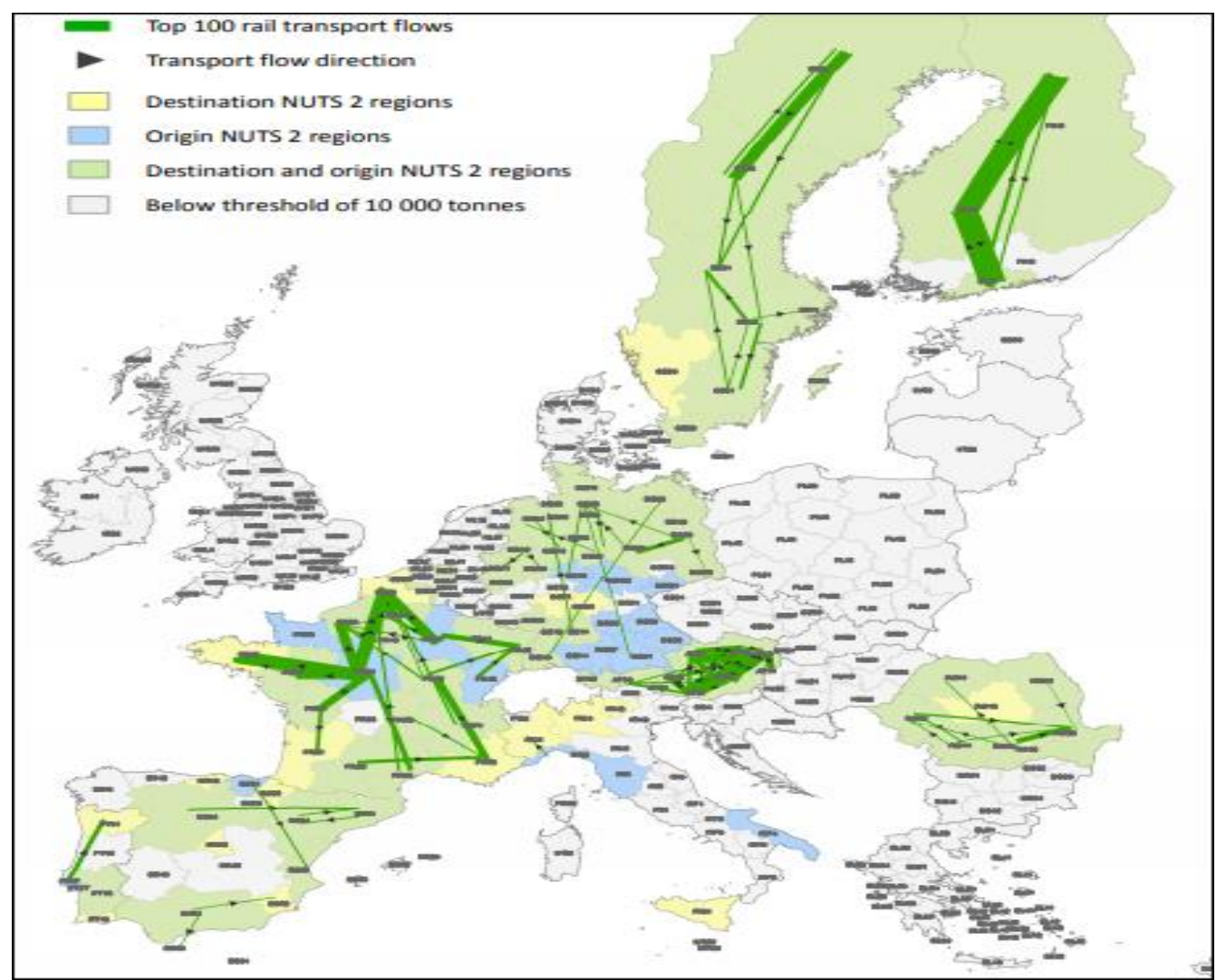

Fig 4: Top 100 national rail transportation flows of agricultural goods in 2015, Study on storage capacities and logistical infrastructure for EU agricultural commodities trade, Final Report, European Commission, Written by Areté s.r.1., November - 2017, pg. $84^{93}$

The biggest quantity of agricultural goods was transported in 2015 from Pahjois to Lansi-Suomi, in Finland (about 1 million tonnes), followed by the flow from Lansi-Suomi to Uusimaa (also Finland, 920,000 tonnes). The third largest quantity was delivered from Centre to Bretagne, in France (780,000 tonnes). Among the first 25 rail freight flows for agricultural goods, 3 are located in Finland, 9 are located in France, 11 are on the Austrian territory, 1 is on the Swedish soil and one is located in Romania (from Muntenia region to the South East region, about 300, 000 tonnes).

\section{RAIL CONNECTIVITY INSIDE EU}

EU rail transport policy is focused, among few other objectives, on the creation of a Single European Railway Area. Three packages and a recast were adopted in the last 20 years, starting the opening-up of the railway sector to competition in 2001. A fourth package, designed to complete the Single European Railway Area, was adopted in April 2016 (the technical pillar) and in December 2016 (the market pillar) $^{94}$.

\footnotetext{
${ }^{93}$ Ibidem.

94 Davide Pernice, Ariane Debyser, Rail transport, Fact Sheets on the European Union, https://www.europarl.europa.eu/factsheets/en/sheet/130/rail-transport, accessed at 01.05.2021.
} 
Basically, the European unity is developed from the backbone of the common transport infrastructure. In order to promote the integration, EU member states agreed to create a number of transport corridors, by rail, by road and by water. The whole idea is to have some "big pipes" for the goods and people, to enhance mobility and connectivity. The task of the Single European Railway Area is the most difficult one for the transport objectives of the Union. Because the member states developed different technologies for electrification equipment, for rail stocks and for traffic management of its own networks. This implies a vast operation of harmonization and standardization for all national states. This consists, first of all in the harmonisation of technical, administrative and safety rules, which is essential to achieve interoperability between national rail systems. Environmental and consumer protection measures may also have to be harmonised to some extent in order to prevent distortions of competition ${ }^{95}$.

The most important technical development which allows the national states to create an extended and performing rail network all over the EU is the so-called ERTMS, European Railway Traffic Management System, a major industrial project developed by eight UNIFE (Union des Industries Ferroviaires Européennes) members - Alstom Transport, AZD Praha, Bombardier Transportation, CAF, Hitachi Rail STS, Mermec, Siemens Mobility and Thales - in close cooperation with the European Union, railway stakeholders and the GSM-R industry. ERTMS consists in the joint presence of two components: ETCS, the European Train Control System, an automatic train protection system (ATP) to replace the existing national ATP-systems and the GSM-R standard, a radio system for providing voice and data communication between the track and the train, based on standard GSM using frequencies specifically reserved for rail application with certain specific and advanced functions. ERTMS is designed to replace 28 different national train control and command systems in Europe. The deployment of ERTMS supports the creation of a seamless European railway system and increase European coherence and consistency.

There are nine rail corridors designed by the member states to unify European railways and to create a performing rail infrastructure within EU:

- Rhine Alpine Corridor, which connects The Netherlands, Belgium, Germany, Switzerland, Italy;

- North Sea - Mediterranean Corridor, which connects The Netherlands, Belgium, France, Luxembourg, Ireland;

- Baltic - Adriatic Corridor, which connects Poland, Slovakia, Czech Republic, Austria, Slovenia, Italy;

- North Sea - Baltic Corridor, which connects The Netherlands, Belgium, Germany, Poland, Lithuania, Latvia, Estonia, Finland;

- Mediterranean Corridor, which connects Spain, France, Italy, Slovenia, Croatia, Hungary;

\footnotetext{
${ }^{95}$ Ibidem.
} 
- Orient - East Med Corridor, which connects Germany, Czech Republic, Slovakia, Austria, Hungary, Romania, Bulgaria, Greece, Cyprus;

- Scandinavian - Mediterranean Corridor, which connects Finland, Sweden, Norway, Denmark, Germany, Austria, Italy, Malta;

- Atlantic Corridor, which connects Spain, Portugal, France, Germany;

- Rhine Danube Corridor, which connects Bulgaria, Czech Republic, Germany, France, Hungary, Austria, Romania, Slovakia

The map seen in Fig.5 is showing how the nine corridors are connecting the EU countries: from the Atlantic Ocean to the German core of the continent, from the British islands to the Mediterranean beach of France, from the north of Poland to the north of Italy, from the Scandinavia to Sicily, from the German ports to the North Sea to the south of Greece and from the Rhine to the Black Sea ${ }^{96}$.

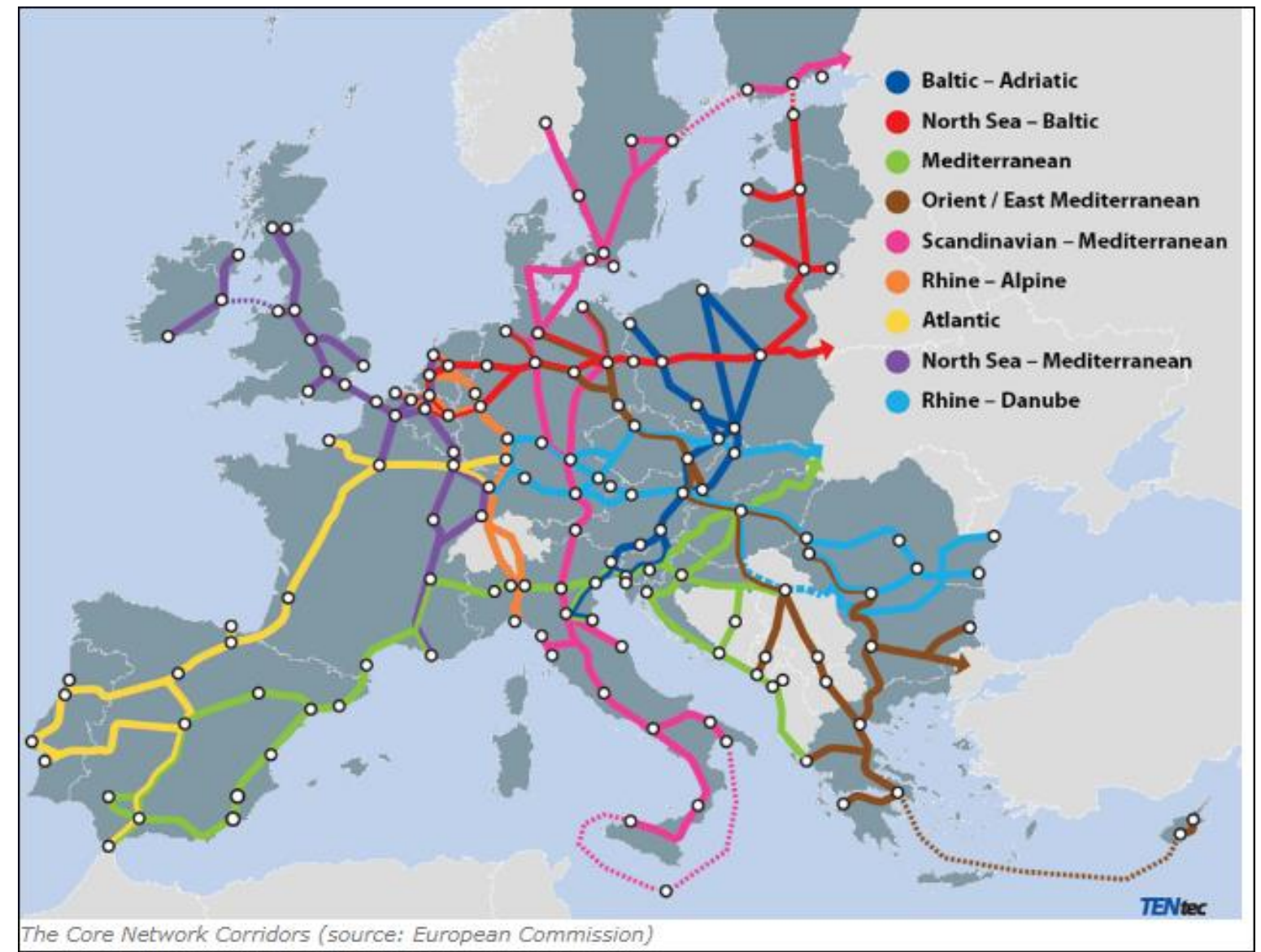

Fig. 5: The Core Network Corridors (source: European Commission), https://www.europeandatajournalism.eu/eng/News/Data-news/How-the-European-Rail-TrafficManagement-System-works-and-why-it-s-not-working ${ }^{97}$

\footnotetext{
${ }^{96}$ How the European Rail Traffic Management System works, EDJNet - The European Data Journalism Network, https://www.europeandatajournalism.eu/eng/News/Data-news/How-the-European-Rail-Traffic-ManagementSystem-works-and-why-it-s-not-working, accessed at 01.05.2021.

97 https://www.europeandatajournalism.eu/eng/News/Data-news/How-the-European-Rail-Traffic-ManagementSystem-works-and-why-it-s-not-working, accessed at 01.05.2021.
} 
For the freight, EU planned rail freight corridors in order to obtain a clear improvement of the rail freight performance versus road freight performance:

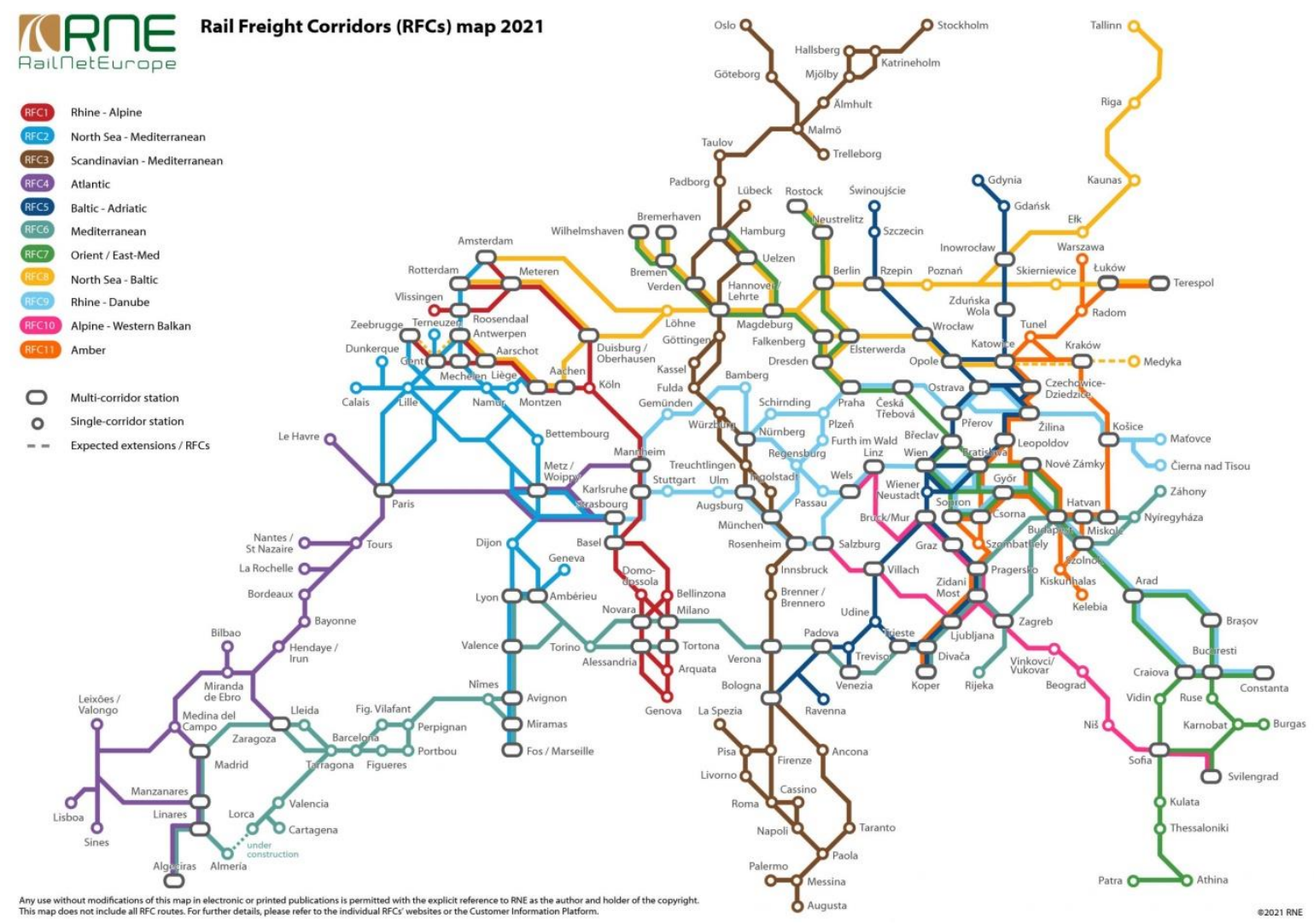

Fig. 6: Rail freight corridors, https://rne.eu/wp-content/uploads/ 2021-04-23_RNE_RFC_Map-scaled.jpg ${ }^{98}$

Feeling the security more intense than the western nations, the eastern member states (former socialist countries) designed a special corridor, from the Baltic Sea to the Black Sea, to promote economic integration but also to create a way for the military supply if necessary. The new corridor, from the Polish port of Gdansk to the Romanian port of Constanta, as in the Fig. 7, was included in the output of the newly created "Three Seas Initiative", formed by the most loyal allies to the US in the East Europe: Poland, Romania and the former socialist countries $^{99}$ :

\footnotetext{
${ }^{98} \mathrm{https} / / / \mathrm{rne} . e u / w p-c o n t e n t / u p l o a d s / 2021-04-23 \_R N E \_R F C \_M a p-s c a l e d . j p g$, accessed at 01.05.2021.

99 Rail-2-Sea- Modernization and development of railway line Gdansk (PL) - Constanța (RO), https://projects.3seas.eu/projects/rail-2-sea-modernization-and-development-of-railway-line-gdansk(pl)constanta-(ro), accessed 15.05.2021.
} 


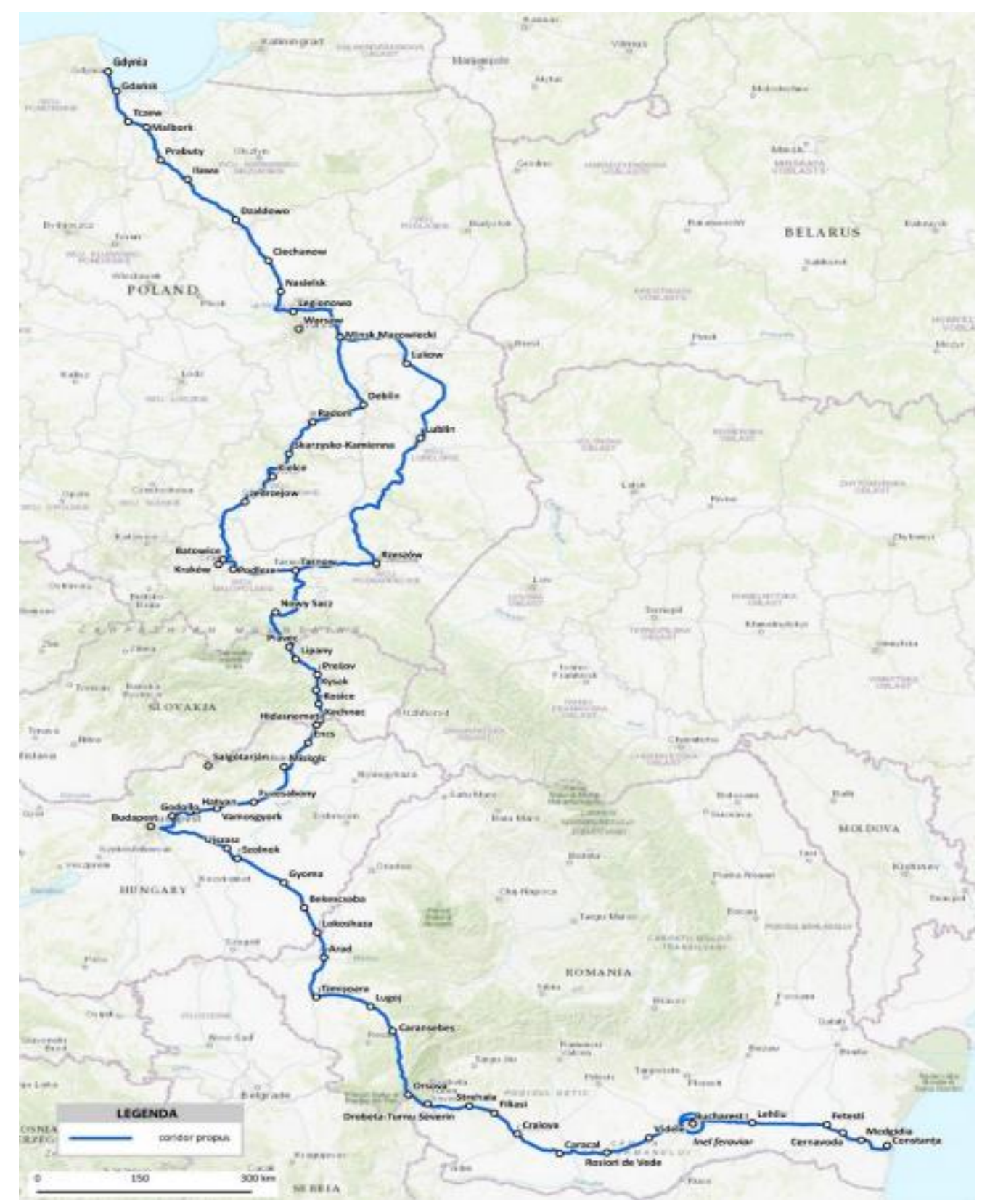

Fig. 7: Constanta-Gdansk rail corridor, https://irp-cdn.multiscreensite.com/ 1805a6e8/files/uploaded/rail2sea\%20Ro\%20presentation\%20ppt\%20v6.pdf ${ }^{100}$

The construction of the railway line between port of Gdansk and port of Constanta crosses four countries: Republic of Poland, Slovak Republic, Hungary and Romania and the total necessary investment is estimated to be 13.832.36 billion. Euro, without VAT, out of which 5.873 .13 billion Euro are secured. The project is funded from EU Cohesion Fund allocated through: Large Infrastructure Operational Programme, Connecting Europe Facility and from the State budget of Romania.

\footnotetext{
100 https://irp-cdn.multiscreensite.com/1805a6e8/files/uploaded/rail2sea\%20Ro\%20presentation\%20ppt\%20v6.pdf,
} accessed at 01.05.2021. 


\section{CONCLUSIONS}

Rail transport is the most promoted mode of transport today by the EU and by member states. Rail is seen now as a source of de-pollution of Europe, as a source of economic prosperity, as a powerful instrument for increasing European trading and also as a very effective way to enhance security. Security is offered through supply chain security for food, energy and other commodities. Security is granted by increasing the feeling of European identity for passengers which are traveling across the continent. Security is also an outcome for the surge in connectivity, which makes room for a very rapid deployment of joint defence resources to the in-danger member state.

\section{BIBLIOGRAPHY}

- Balog M., Sokhatska H., Iakovets A., Intelligent Systems in the Railway Freight Management, Special Session SS02 "Intelligent Manufacturing Systems" within the Conference "Manufacturing 2019" (May, 19-22, Poznan, Poland).

- Brown H. (1983), Thinking about national security: defense and foreign policy in a dangerous world. As quoted in Watson C.A., (2008), U.S. national security: a reference handbook, Contemporary world issues (2 (revised) ed.). ABC-CLIO. pp. 281. ISBN 978-1-59884-041-4, https://archive.org/details/ usnationalsecuri0000wats.

- European Year of Rail, European Commission, Directorate-General for Mobility and Transport, https://europa.eu/year-of-rail/why-rail_en.

- Greenhouse gas emissions: a decisive asset for rail?, https://www.climatechance.org/wp-content/uploads/2019/03/new-greenhouse-gas-emissions-adecisive-asset-for-rail.pdf.

- How the European Rail Traffic Management System works, EDJNet - The European Data Journalism Network, https://www.europeandata journalism.eu/eng/News/Data-news/How-the-European-Rail-TrafficManagement-System-works-and-why-it-s-not-working.

- Inland transport infrastructure at regional level, Eurostat, Statistics Explained, https://ec.europa.eu/eurostat/statistics-explained/index.php?title= Inland_transport_infrastructure_at_regional_level\&oldid=482435\#Railways.

- Pernice D., Debyser A., Rail transport, Fact Sheets on the European Union, https://www.europarl.europa.eu/factsheets/en/sheet/130/rail-transport. 
- Regional GDP per capita ranged from $32 \%$ to $260 \%$ of the EU average in 2019, European Commission, Eurostat, 03/03/2021, https://ec.europa.eu/ eurostat/web/products-eurostat-news/-/ddn-20210303-1.

- Rail-2-Sea-Modernization and development of railway line Gdansk (PL) Constanța (RO), https://projects.3seas.eu/projects/rail-2-sea-modernizationand-development-of-railway-line-gdansk(pl)-constanta-(ro).

- Study on storage capacities and logistical infrastructure for EU agricultural commodities trade, Final Report, European Commission, Written by Areté s.r.1., November - 2017, https://ec.europa.eu/info/sites/default/files/foodfarming-fisheries/plants_and_plant_products/documents/storagecapabilities-cop-report_nov2017_en.pdf.

- The Economic Footprint of Railway Transport in Europe, Ecorys for Client: Community of European Railway and Infrastructure Companies (CER), Brussels, October 2014, https://www.cer.be/sites/default/files/publication/ The_Economic_Footprint_-_web_-_final_final_30_Sept_0.pdf.

- The European Rail Traffic Management System, UNIFE, https://www.ertms. net/?page_id=40. 